\title{
THE CHALLENGES OF REGULATING AND ENFORCING COMPETITION LAW (BUCHAREST 14 - 15 NOVEMBER 2019)
}

\author{
Ondrej Blažo \\ Comenius University in Bratislava
}

On $14-15$ November 2019, the Faculty of Law of the Bucharest University, particularly the Centre of Competition Law Studies, and the Competition Council of Romania co-organized the international scientific conference "The Challenges of Regulating and Enforcing Competition Law". The conference's scientific committee led by Adriana Almăşan put together senior scholars affiliated with universities of fourteen European countries (Belgium, Denmark, France, Germany, Greece, Hungary, Italy, the Netherlands, Portugal, Romania, Slovakia, Spain, Sweden and the United Kingdom), the judge of the General Court of the Court of Justice of the European Union and the president of the Competition Council of Romania (Romanian national competition authority) to discuss challenges and limits of substantive and procedural competition law. The conference was held in Aula Magna of the Bucharest University with more than 300 registered participants. The conference was split into the introductory panel, seven panels (not strictly focused only on one issue) and the conference was followed by the seminar for judges from the High Court of Cassation and Justice and the Courts of Appeal.

Procedural and institutional framework of the application of competition law (European and national) was discussed several times during the conference. B. Chirițoiu (president of the Competition Council of Romania) described limits of institutional framework of application of competition law in Romania. Limits of judicial review on the EU level, particularly within the General Court were analysed by Judge A. M. Collins (title of presentation: Some limitations on the judicial enforcement of competition law). Independence of NCAs was under scrutiny of A. Almăşan of the University of Bucharest (Rose is a rose is a rose: the NCA autonomy within the ambit of ECN+ Directive). The ECN+ Directive sets the autonomy of the NCAs as a general principle, paramount for the consistent application of competition law within the European Union. This objective is heavily challenged however, at practical level, by the financial autonomy, the appointment of the NCA decisional bodies, the political system enabling interference and even the competence of the operational staff of the NCA. The presentation tackled the most relevant challenges in search for both the level of risk entailed by each challenge and possible solutions thereto. The theoretical analysis was confronted with the status of application of competition law in Romania. Institutional challenges were also linked to the presentation of Cs. I. Nagy of the University of Szeged (EU competition law's centralized interpretation and decentralized enforcement: procedural challenges). The enforcement of EU competition law features a remarkable peculiarity that distinguishes it from other antitrust/ competition systems: it is a unitary/centralized system in terms of substantive law and (partially) decentralized in terms of enforcement. This dichotomy, which is attributable to the very special structure of EU law's enforcement at large, raises various practical issues concerning both public and private enforcement and impacts on the effectiveness of EU competition law. He analysed the efforts EU law has made to increase the effectiveness of EU competition law's enforcement, while respecting Member States' procedural autonomy within the map of vertical and horizontal effects of EU law, raising also question of "diagonal" effect of EU rules of procedure. 
M. Martyniszyn of Queen's University Belfast (Competitive Harm Crossing Borders: Regulatory Gaps and a Way Forward) was trying to find a solution for enforcement of competition law at the international level. The analysis identified some of the key gaps within this regulatory framework which currently allows for enforcement lacunae, providing room for transnational anticompetitive practices to flourish at the expense of consumers, principally in the less resourceful and less developed states. Many states have introduced competition laws and an international consensus has emerged as to the harmful nature of some of the most damaging types of anticompetitive arrangements. Yet gaps persist that were not addressed by the significant growth in contacts and cooperation between competition law enforcers all over the world. The speaker's proposals focused, in particular, on pursuing international cartels, which constitute the most rampant example of competition law violation and which are virtually universally condemned. Implementation of these proposals requires no international negotiations and most carry little, if any, inherent extra cost. If implemented by a sufficient number of states (a bottom-up regulatory change), these proposals would importantly readjust the currently sub-optimal system of enforcement, which gives violators ample opportunities to extract wealth from less affluent states.

Private enforcement of competition law became a thoroughly discussed topic among scholars and practitioners within the EU. M. Sousa Ferro of the University of Lisbon (Antitrust damages in the EU: lessons and dreams) discussed the possibility, or more precisely the impossibility, of proving violation of competition law at national courts, particularly in stand-alone cases. The second step of private enforcement - definition of compensation - was examined by E. Camilleri of the University of Palermo (The right to full compensation in passing-on cases).

Relationship between competition law ("traditional" antitrust) and unfair business practices, including B2B practices, is a political as well as a legal question of competence of EU Member States and NCAs. Ever more Member States are making use of the mandate under Regulation 1/2003 to adopt rules against the abuse of economic dependence or unfair trade practices. W. Devroe of the KU Leuven and the Maastricht University (Abuse of economic dependence), on the basis of practical examples and in a context of convergence between competition law and B2B unfair market practices law, focused on: (a) the nexus (buyer power) and differences with traditional competition law, (b) the diversity of national regulatory options, (c) the advantages and disadvantages of the options and their diversity, and (d) the impact of Directive (EU) 2019/633 on unfair B2B trading practices in the agricultural and food supply chain. M. Behar-Touchais of the University of Paris 1 Panthéon-Sorbonne (The conflict between European antitrust law and national law of unfair commercial practices B to B: the Booking case) identified several examples when French law against unfair $\mathrm{B} 2 \mathrm{~B}$ practices may undermine antitrust law.

Current competition law was also tested in the context of digital markets and current case law and decision practice were under scrutiny. B. Oppermann of Leibniz University of Hannover (Market Law Aspects of Automatic and Autonomous Driving) showed challenges for competition law in the sector of autonomous cars, e.g. consumer and data protection, modifications of distribution contracts, and consequences for market law and competition law.

A. Gerbrandy of the Utrecht University (The challenges of applying competition law in the digital economy) focused on powerful positions of Big Technology companies and the response of competition law, the interplay between competition law and other regulatory regimes and the application of the cartel prohibition in the digital arena. Critical assessment of "Google Shopping Decision" was brought by Ch. Bergqvist of the University of Copenhagen (What does EU 2017 Google Shopping 
Decision tell us about self-favouring as a competition law infringement?). During the late $2000 \mathrm{~s}$, several jurisdictions, including the EU and the U.S., opened investigations into potential antitrust violations by the Internet search firm, Google, for alleged bias in the ranking of the links returned in response to search queries. While the outcome has differed substantially between jurisdiction, the factual allegations against Google are almost indistinguishable. Moreover, EU decision, and the articulated theory of abusive self-favouring, have formed the core of parallel investigations into other IT-companies making it relevant to dissect the theory of abusive self-favouring under Article 102 TFEU.

Dynamic development of competition issues is not only stemming from "new" sectors of economy, such as digital markets, but involves also more traditional sectors. Both D. Tzouganatos of the University of Athens (Selective Distribution and third-party online platforms - In Search of the Scope of the Coty Rules) and L. Bercea of the West University of Timișoara (Market for Lemons under Pressure: Recent Developments in ECJ Case-Law on Price Transparency) analysed impact of vertical agreements, however form different point of views. On the basis of Coty and Pierre Fabre judgments, D. Tzouganatos claimed that the scope of the legality presumption of the ban on thirdparty platform sales in a selective distribution system is not entirely clear. In particular, whether it applies merely to luxury goods and what is the definition of luxury goods. The presentation of L. Bercea critically analysed the evolution of recent CJEU case law on price transparency in consumer credit agreements, which supplements the standard of informative transparency, introducing several requirements on the explanatory transparency and influencing the competitive advantages of non-transparent sellers or suppliers.

In the context of dynamic development of EU competition law, relationship to intellectual property rights must be taken into account. Conciliation between these two legal regimes was suggested in the presentation of D. Trăilă of the University of Bucharest (Practical aspects of conciliation between the monopoly rights attached to the IP and the competition regulations).

Current issues of merger regime caught attention of F. Marcos of IE Law School (Design of Merger Control in the EU and beyond: Institutions and Procedure) and J. Nowag of the Lund University (The unintended consequences of EU merger control in the time of protectionism). J. Nowag identified that the protection offered to large (often multinational) companies under the EUMR against protectionist measures is greater than that offered to small and medium-sized companies within the general framework of EU law.

Activities of public authorities and their impact on competition law was also one of the topics of the conference. M. Papp of Eötvös Loránd Research Institute of Budapest (The Transformation of EU State Aid Law and Policy) identified challenges for new decentralized system of state aid. S. Gherghina of the University of Bucharest (State Aid for SGEI Entrusted to Public Companies) analysed, by reference to specific challenges and practice of Romanian authorities, the identification of the SGEI and its relation to the Altmark criteria in order to identify the thin domain where the financing from public funds of public companies is compatible with the EU law provisions protecting the free competition. O. Blažo of Comenius University in Bratislava (Protection of competition and public procurement integrity protection - true couple or marriage of convenience?) analysed different measures for securing integrity of public procurement vis-à-vis bid rigging suggesting that, on the one hand, competition law is the most effective enforcement weapon, but, on the other hand, it can easily turn NCA into "bid-rigging agency".

The presentations of the conference are planned to be materialized in an edited volume in 2020 . 


\section{Contact information:}

doc. JUDr. Ing. Ondrej Blažo, PhD.

ondrej.blazo@flaw.uniba.sk

Comenius University in Bratislava, Faculty of Law

Šafárikovo nám. 6

81000 Bratislava

Slovakia 
